ОБУХОВ Леонид Аркадьевич - кандидат исторических наук, доцент кафедры междисциплинарных исторических исследований Пермского государственного национального исследовательского университета (614990, Пермь, ул. Букирева, 15; obuhovla@yandex.ru)

ЕХЛАКОВА Алина Ринатовна - ассистент кафедры междисииплинарных исторических исследований Пермского государственного национального исследовательского университета (614990, Пермь, ул. Букирева, 15; alina.perm@mail.ru)

\title{
ПЕРИОДИЧЕСКАЯ ПЕЧАТЬ КАК ИСТОЧНИК ПО ИСТОРИИ ИНФОРМАЦИОННОГО ПРОТИВОБОРСТВА КРАСНЫХ И БЕЛЫХ В ГРАЖДАНСКОЙ ВОЙНЕ НА ВОСТОКЕ РОССИИ (1917-1920 гг.)
}

\begin{abstract}
Аннотация. На материалах ряда уральских газет рассматривается информационное противоборство красных и белых 1 в период Гражданской войны на востоке России. Именно газеты являлись самым массовым и популярным средством информации и важным орудием в информационной войне. Отмечается, что если большевики имели достаточно налаженный агитационно-пропагандистский аппарат и большие тиражи газет, то их противникам пришлось начинать все заново. Авторы выделяют общее и особенное в этом противостоянии, различия в подходах государственных, партийных и независимых изданий и раскрывают, какие факторы оказали влияние на победу красных в информационной войне.

Ключевые слова: Гражданская война, информационная война, информационное противостояние красных и белых, газетная периодика, восток России
\end{abstract}

$\Gamma$ ражданская война в России - это не только боевые действия, но и информационное противоборство сторон. Основным элементом этого противоборства, помимо листовок и брошюр, выступала периодическая печать. Она являлась не только источником информации, но и инструментом формирования общественного мнения, идейно-политической борьбы за массы. От этого в немалой степени зависел исход Гражданской войны.

Периодическая печать периода Гражданской войны представляет огромный интерес для исследователей, поскольку дополняет, а иногда и восполняет архивные источники. Поэтому вполне понятен интерес историков к этому, пусть и субъективному, источнику. Если в советский период основное внимание уделялось партийно-советской печати, то в постсоветский период - антибольшевистским изданиям. Прежде всего, следует отметить работы Л.А. Молчанова, в которых автор, помимо описания условий функционирования периодики в условиях революции и Гражданской войны, анализирует и содержание большевистских и антибольшевистских газет [Молчанов 2001; 2002]. Особенно активно исследуют периодику этого периода сибирские историки [Никитин 1991; Волгин 1990]. Из уральских исследователей можно отметить И.В. Нарского, который в приложении к своей монографии приводит список уральских газет периода 1917-1922 гг. [Нарский 2001: 592-604]. Хотя в этом списке имеются некоторые неточности, тем не менее, это наиболее полный список уральских газет на сегодняшний день. К анализу газетной периодики

\footnotetext{
1 Под белыми достаточно условно понимаются все противники большевиков. Считать белыми Комуч, Временное сибирское правительство, Временное областное правительство Урала нет оснований.
} 
обращались и зарубежные исследователи, но лишь для раскрытия отдельных сюжетов, не обращаясь непосредственно к проблеме идейного противоборства [Карр 1990; Рабинович 1989].

К сожалению, вопрос информационного противоборства красных и белых рассматривается в имеющихся публикациях довольно кратко, порой без должной конкретики. Это и понятно, поскольку авторы не ставили своей задачей подробное исследование этого вопроса. Основное внимание уделяется количественным показателям, типологии, отношениям с властью. Если же исследователи обращались к данной теме, то чаще всего рассматривали визуальные источники [Наталенко 2017; Куваева, Балашова 2016; Заранян 2016]. Газетная периодика в этих исследованиях анализируется крайне неполно и ограниченно.

В данной публикации на примере нескольких газет Урала предпринимается попытка выявить общее и особенное в информационном противоборстве красных и белых, особенности кадрового состава, различия в подходах государственных, независимых или партийных изданий в информационной войне.

Большевики сразу после захвата власти в Петрограде резко ограничили информационное пространство своих политических противников. 27 октября Совнарком утвердил декрет о печати, по которому подлежала закрытию «контрреволюционная печать разных оттенков». Затем последовало решение о конфискации частных типографий, запасов бумаги и передаче их в собственность советской власти. 7 ноября Совнарком принял декрет «О введении государственной монополии на объявления», что лишило независимые издания одного из источников финансирования.

Если в центре в первые месяцы после установления власти большевиков была закрыта сравнительно небольшая часть «контрреволюционных» газет, а массовое закрытие последовало в августе-сентябре 1918 г., то на местах, в т.ч. на Урале, уже к февралю газет основных политических противников большевиков (кадетов, меньшевиков, правых эсеров) практически не осталось. Коегде выходили короткое время и нерегулярно издания левых эсеров, анархистов и эсеров-максималистов. Некоторые издания были восстановлены в 1919 г. В одном из первых выпусков редакция газеты «Свободная Пермь» не преминула опубликовать статью с обвинением большевиков в закрытии газеты ${ }^{1}$. Но большевики столкнулись с другой проблемой - кадровой. Так, один из руководителей пермских большевиков М.Н. Лукоянов отмечал: «Интеллигенция, за исключением немногих, идет не с нами» ${ }^{2}$. Это не могло не отразиться на уровне большевистских изданий. Если небольшевистские издания умерили критику новой власти, то большевики - наоборот. Так, «Пролетарское знамя» назвало меньшевистскую «Пермскую жизнь», с которой многие большевики в свое время сотрудничали, «органом новых черносотенцев», а городскую думу, где социалисты составляли большинство, - «очагом контрреволюции» 3 .

В период борьбы с Калединым в советских газетах появляется рубрика «В калединском царстве», а после восстания чехословацкого корпуса - «В царстве чехословаков и белогвардейцев», «В царстве контрреволюции» ${ }^{4}$. Понятие «царство» ассоциировалось с «царским самодержавием» и воспринималось

1 Свободная Пермь. 1919. 21 января.

2 Пролетарское знамя. 1917. 1 декабря.

3 Пролетарское знамя. 1917. 6 декабря.

4 Известия Пермского губернского Исполнительного комитета Советов рабочих $u$ солдатских депутатов. 1918. 6 января, 20 июня; Бюллетень Пермского губернского Военнореволюционного комитета. 1918. 11 августа. 
широкими народными массами крайне негативно, что и использовали большевики в своей пропаганде. Описание творящегося произвола должно было показать, что ждет трудящиеся массы в случае свержения советской власти: «в Челябинске Совет разгромлен, его вожди казнены. Профессиональные союзы и все общественные и рабочие организации разгромлены... Земли и предприятия возвращены владельцам и кулакам. ‘..> трудно учесть убитых и арестованных, но уже обширной челябинской тюрьмы не хватает». «Ужасы Варфоломеевской ночи буквально меркнут перед тем, что проделывают эти банды звероподобных людей... Белый террор палачей трудового народа не знает границ». «Чехословаки в бой идут пьяными. Спирт везут за собой. В городах, занятых чехословаками - пьянство, грабежи» ${ }^{1}$.

В «белых» газетах власть большевиков нередко также ассоциировалась с царским режимом: «здравый смысл упразднен, наука признана контрреволюционной и отдана под надзор самодержавных комиссаров» 2 , «советский пал диктатор - подобие царя» ${ }^{3}$. А иногда даже большевистская власть называлась игом: «Сибирь сбросила советское иго» 4 .

Чехословаки же, в противоположность советским газетам, представлялись как добровольцы, борющиеся за свободную Россию 5 .

Довольно часто газеты как красных, так и белых печатали рассказы «очевидцев», что должно было придать большую убедительность и достоверность этим сообщениям. Так, не названный член исполкома Омского Совета сообщил удивительные цифры о потерях в боях за Омск: «В боях за Омск чехословаки потеряли 4500-5000 человек, советские войска потеряли 200-500»6. Тенденция завышать потери противника и преуменьшать свои - характерная черта как красных, так и белых.

Летом 1918 г. в условиях разгоравшейся гражданской войны большевистская печать рисовала картину скорой победы над контрреволюцией, разложения и противоречиий в стане белых, роста революционных выступлений. «Иркутск в руках Советов, от Владивостока против чехословаков идут матросы, рабочие в городах выносят резолюции за советскую власть... Военных сил у “Сибирского правительства” кроме чехословаков и кучек офицерства нет...»7. «Часы чехословацко-белоэсеровско-меньшевистской контрреволюции сочтены. Повсюду наши доблестные красноармейские части одерживают верх над врагом» 8 . Зеркальным отражением публикаций большевистских газет были публикации антибольшевистских изданий, рисовавшие картину полного упадка советского тыла, разложения Красной армии, роста недовольства рабочих и крестьян, с нетерпением ожидавших освобождения от власти большевиков: «красноармейцы, узнав о движении колонны наших... сдались почти без боя, боясь быть отрезанными... Сопротивление оказали только незначительные банды, засев-

\footnotetext{
1 Известия Пермского губернского Исполнительного комитета Советов рабочих $u$ солдатских депутатов. 1918. 20 июня, 21, 23, 28 июля.

2 Власть народа. 1918. 22 июня.

3 Власть народа. 1918. 23 июня.

4 Власть народа. 1918. 2 июля.

5 Наш Урал. 1918. 20 ноября.

6 Известия Пермского губернского Исполнительного комитета Советов рабочих $u$ солдатских депутатов. 1918. 22 июня.

7 Известия Пермского губернского Исполнительного комитета Советов рабочих $u$ солдатских депутатов. 1918. 21 июля.

8 Известия Пермского губернского Исполнительного комитета Советов рабочих $u$ солдатских депутатов. 1918. 14 сентября.
} 
шие на вокзале... Жители многих деревень, занятых большевиками, переходят со всем своим имуществом в тыл расположения наших частей» 1 .

Одним из следствий неудач на фронте явилось закрытие в Екатеринбурге последней небольшевистской газеты «Уральская жизнь» в июне 1918 г. по приказу командующего Северо-Урало-Сибирского фронта Р.И. Берзина «за разглашение военной тайны» ${ }^{2}$. В то же время значительно увеличиваются тиражи «Известий Уральского областного Совета» (до 16-17 тыс. экз.) и «Уральского рабочего» (до 15 тыс.) ${ }^{3}$.

Газеты красных и белых регулярно публиковали сводки с театров военных действий, заметки и статьи, представлявшие действия своих войск в более выгодном свете, а противника - в самом негативном. Успешное наступление описывалось подробно, с деталями, а отступление - очень обтекаемо, кратко - как «отход на заранее подготовленные позиции». Показательно в этом отношении объяснение оставления Екатеринбурга красными войсками: «25 июля наши части, не желая подвергать Екатеринбург артиллерийскому обстрелу, оставили его в полном порядке и отошли на заранее подготовленные позиции» ${ }^{4}$. Аналогично старались показать успехи и неудачи редакции «белых» газет: «ввиду введения противником в бой свежих значительных сил, [наши] оставили город Белорецк, захватив с собой 25 пленных, 5 отобранных у противника пулеметов»5.

По-разному использовали газеты тему террора. Большевики провозгласили «красный террор» государственной политикой. В их газетах в 1918-1919 гг. регулярно появлялись заметки о раскрытых контрреволюционных заговорах и расстрелах, публиковались списки расстрелянных и заложников, сообщения о расстрелах ЧК в разных городах страны. Печатались крайне жесткие приказы и обращения командования 3-й армии. Так, в конце августа 1918 г. был опубликован приказ Р.И. Берзина, по которому все деревни, в которых происходят восстания, предписывалось «снести артиллерийским огнем с лица земли» 6 . В сентябре было опубликовано распоряжение командующего особыми отрядами 3-й армии Ю.Ю. Аплока: «...волости и деревни, в которых будет замечено контрреволюционное выступление, будут мною снесены с лица земли. <... В случае покушения или убийства кого-либо из советских работников, матросов или красноармейцев, мною будут тотчас же расстреляны 10 человек из буржуазии, а при повторении такого случая, я не остановлюсь перед тем, чтобы увеличить эту репрессию еще в несколько раз» 7 . Любопытным было оправдание массовых расстрелов: «Мы не мстим, мы боремся за человечество, устраняя неприспособленных» ${ }^{8}$. Широко практиковалась коллективная ответственность: за порчу телефонных проводов отвечала в целом волость, в районе которой обнаружены повреждения; за обнаружение в деревне «белогвардейских

\footnotetext{
1 Власть народа. 1918. 14 июля.

2 Известия Пермского губернского Исполнительного комитета Советов рабочих $u$ солдатских депутатов. 1918. 27 июня.

3 Известия Пермского губернского Исполнительного комитета Советов рабочих $u$ солдатских депутатов. 1918.7 июля.

4 Известия Пермского губернского Исполнительного комитета Советов рабочих $u$ солдатских депутатов. 1918. 30 июля.

5 Власть народа. 1918. 14 июля.

6 Известия Пермского губернского Исполнительного комитета Советов рабочих $u$ солдатских депутатов. 1918. 30 августа.

7 Известия Осинского уездного исполнительного комитета Советов крестьянских, рабочих и армейских депутатов. 1918. 25 сентября.

8 Там же.
} 
бандитов» отвечала вся деревня ${ }^{1}$. В 1919 г. продолжали публиковаться списки расстрелянных губЧК и по приговорам ревтрибунала, но уже не столь массовые $^{2}$. Все эти меры были призваны запугать народ, ощущение страха делало его послушным.

Иное отношение к террору было в газетах белых. Никаких призывов к «белому террору», списков заложников и расстрелянных. Публиковались отдельные сообщения о задержаниях большевиков за большевистскую агитацию и передаче задержанных в руки военного контроля. Были и заметки о расстрелах, но, как правило, за уголовные преступления и злостное дезертирство. Одним из методов борьбы с неблагонадежными было выселение из пределов расположения Сибирской армии и Пермской губернии ${ }^{3}$. Своеобразным доносом под заголовком «Вниманию, кого следует» явились публикации в «Пермских губернских ведомостях» списка на 30 коммунистов и советских работников, выявленных по советской печати. Газета призывала граждан дать знать властям, если им известно местонахождение данных лиц, и вообще указывать на «притаившихся» большевиков ${ }^{4}$.

Белый террор был, но он не являлся официальной политикой, а стыдливо назывался «экзекуциями». В газетах об этих «экзекуциях» практически не писали, но о том, что белые творили произвол в отношении населения, устраивали порки, бессудные расстрелы, грабежи, свидетельствуют официальные документы. Так, приказ командующего Сибирской армией Р. Гайды признавал расправы, порки и расстрелы без суда недопустимыми. «Кто будет самочинно творить экзекуции, расправы и расстрелы, предавать военно-полевому суду»5. В приказе Верховного правителя адмирала А.В. Колчака от 6 мая 1919 г. подчеркивалось: «...войска должны вести себя так, чтобы население относилось к ним с уважением и благодарностью... Войска и население должны видеть друг в друге братьев. Все должно совершаться на основании закона». Приказ предписывал установить порядок платы населению за забираемые продукты, фураж, подводы и пр. ${ }^{6}$

При описании «царства контрреволюции» большевистская печать основное внимание уделяла описаниям зверств белых, разложению тыла и армии, выступлениям рабочих и крестьян против белогвардейской диктатуры. В публикациях, начиная с июня 1918 г., говорилось о близком крахе контрреволюции, однако этот «близкий крах» растянулся до 1920-1921 гг. Значительная часть информации о положении в тылу белых вызывает большие сомнения, как, например, утверждение, что по распоряжению Сибирского правительства были расстреляны свыше 41 тыс. рабочих с женами и детьми ${ }^{7}$.

«Белая» печать, помимо описаний ужасов «красного террора», выступлений рабочих и крестьян против большевистской диктатуры, намного больше внимания уделяла положению с продовольствием, топливному голоду, эпидемиям, особенно в Москве и Петрограде. Так, в заметке «Москва под гнетом» утверждается, что город совершенно запущен, жители встают и ложатся с мыс-

\footnotetext{
1 Красный Урал. Листок объявлений. 1919. № 26.

2 В январе 1920 г. постановлением ВЦИК и Совнаркома смертная казнь отменена, но уже в мае 1920 г. реввоентрибуналы получили право выносить смертные приговоры.

3 Государственный архив Пермского края (ГАПК). Ф. Р-656. ОП. 1. Д. 3. Л. 46, 48; Д. 8. Л. 8 .

4 Пермские губернские ведомости. 1919. 15, 22 июня.

5 Пермская земская неделя. 1919. 18 мая.

6 Сибирские стрелки. 1919. 13 мая.

7 Известия Пермского губернского Исполнительного комитета Советов рабочих $u$ солдатских депутатов. 1918. 27 сентября.
} 
лью о куске хлеба. Приводятся цены на продукты: пуд муки - 800 руб., мясо коровье -35 руб. фунт, конина - 16 руб. фунт, собачье мясо - 3 руб. 50 коп., масла нет вообще. В этом же номере приведены цены Пермского общества потребителей: масло - 9 руб. фунт, белый хлеб - 2 руб. 80 коп. фунт, рис -2 руб. 80 коп. фунт и т.д. 1 Через месяц в заметке «Вести из Москвы» цены выросли в 2 раза и добавилось еще кошачье мясо по 5 руб. за фунт ${ }^{2}$.

Но порой в газетах приводятся такие факты, в которые просто невозможно поверить. Примером этого может служить публикация со ссылкой на сообщение РТА «Хлеб из мха»: «Советские газеты сообщают, что в Москве была устроена выставка пищевых продуктов из голландского мха. Были выставлены образцы этого мха и хлеб из него пополам с ржаной мукой. Советские газеты уверяют, что хлеб этот прекрасного вкуса и по питательности не уступает ржаному. Выпечка такого хлеба началась в городских пекарнях. Ввиду недостатка жировых веществ некоторые мыловаренные заводы приступили к выработке мыла из торфа и глины» 3 . Столь же неправдоподобным выглядит и сообщение «Голодный бунт в Москве» со ссылкой на агентство «Рейтер»: «На массовом митинге рабочие кричали: “Долой Ленина, Троцкого и голодную республику”. Красноармейцы разогнали демонстрацию и произвели резню. Расстреляно и переколото штыками до 4000 человек» 4 .

В одном из обращений правительства А.В. Колчака делается вывод, с которым трудно не согласиться: «советская власть поддерживается тремя чудовищными средствами - голодом, террором и гражданской войной» 5 .

Большевики имели налаженный агитационно-пропагандистский аппарат, в отличие от различных антибольшевистских режимов, которые организовывали этот аппарат с чистого листа. Это признавали и их противники: «Большевиками дело агитации поставлено образцово, - отмечалось в статье «Неотложная задача, - то же самое необходимо сделать и нам» 6 . «Большевики крайне приучили население к печатному слову... необходимы газеты, воззвания, листовки, брошюры, осведомляющие население о происходящем, написанные простым и ясным языком», - говорилось в передовой статье 7 .

В стремлении к упрощению своих изданий некоторые газеты стали публиковать якобы советские частушки: «Я десертом угощу моего миленочка,/ Из духовки притащу свежего мышоночка» 8 .

С опозданием началось создание агитационно-пропагандистского аппарата при А.В. Колчаке. При правительстве организовано Бюро печати, которое возглавил профессор Пермского университета Н.В. Устрялов. Он разрабатывает и реализует агитационно-пропагандистскую стратегию омской власти. Под его руководством Бюро стало своего рода информационным агентством правительственной информации. В качестве директора Устрялов создает работоспособную информационную структуру, ориентированную на военных и гражданское население. Кроме того, в Главном штабе адмирала А.В. Колчака был образован Осведомительный отдел (Осведверх), руководивший осведомительными органами колчаковских армий и выпускавший бюллетень для военных газет. При штабе Сибирской армии создано информационное отделение, занимав-

1 Сибирские стрелки. 1919. 18 февраля.

2 Сибирские стрелки. 1919. 16 марта.

3 Освобождение России. 1919. 20 марта.

4 Сибирские стрелки. 1919. 15 мая.

5 Сибирские стрелки. 1919. 25 февраля.

6 Сибирские стрелки. 1919. 8 марта.

7 Сибирские стрелки. 1919. 10 апреля.

8 Сибирские стрелки. 1919. 9 мая. 
шееся распространением газет. Однако штат его был явно недостаточным: в штабе корпуса и в дивизиях назначался один офицер, заведующий экспедицией, и 2 солдата в помощь ${ }^{1}$. Летом 1919 г. в обстановке начавшихся неудач на фронте пропаганде стало уделяться особое внимание. Не в пользу белых играло и военное положение в прифронтовых районах, что приводило к приостановке изданий «по распоряжению военных властей» 2 , из-за цензуры ${ }^{3}$ или просто плохой работы почты.

Газеты были самым массовым и популярным информационным средством в годы Гражданской войны. Но если на территории Советской России всю печать контролировали большевики, то на той части России, которая находилась под властью антибольшевистских правительств, допускалось издание оппозиционных газет, пусть и в ограниченном масштабе, умеренная критика властей, различные оценки событий. Любопытную характеристику местной печати дают в редакционной колонке «Сибирские стрелки»: «Неясное представление о задачах государственных, погоня за наживой, сенсацией, полная неопределенность физиономии или, с другой стороны, чересчур резкая партийность - вот что характеризует местные органы» 4 . Подобного не могло быть в советских газетах.

По данным «Правительственного вестника», на территории, контролируемой правительством А.В. Колчака, выходили 209 периодических изданий - 117 газет и 92 журнала, в т.ч. 6 социалистических, 14 демократических, 18 прогрессивных, 4 правых, 9 военных и 19 официальных. Остальные - общественно-политические, литературные и экономические или «беспартийные». На апрель 1919 г. в Екатеринбурге выходили 5 газет и 7 журналов, в Омске 8 газет и 15 журналов $^{5}$. В Перми выходили 7 газет и 4 журнала. Газеты определенной политической направленности часто цитировали публикации друг друга, а уральские «белые» газеты перепечатывали и статьи из сибирских газет.

В целом структура «красных» и «белых» газет повторяла издания досоветского периода, поэтому как логическая композиция самих выпусков, так и многие рубрики и типы публикаций были одинаковыми во всех изданиях. Выстраиваемые с помощью публикаций в газетах образы власти в определенный временной промежуток пересекались, влияли друг на друга.

Основными читателями газет являлись представители средних слоев, городские жители. Манера изложения материала, язык колчаковских газет в большей мере рассчитаны на интеллигентного читателя. В этом отношении большевики подавали материал в своих газетах более просто и доступно. Уже в годы Гражданской войны советская власть уделяла большое внимание ликвидации безграмотности, особенно в Красной армии. Популярный призыв большевистских газет: «Товарищ, если ты грамотен, - прочти газету неграмотному» 6 . Большую агитационно-пропагандистскую работу проводили политотделы, комиссары и агитаторы в войсках, читавшие лекции, проводившие беседы, устраивавшие публичные читки газет. Не следует сбрасывать со счета и партийные организации в армии. У белых, напротив, постановлением правительства А.В. Колчака офицерам, военным врачам, чиновникам, солдатам, матросам, а также вольнонаемным служащим в военных учреждениях участие в поли-

\footnotetext{
1 Сибирские стрелки. 1919. 17 апреля.

2 Наш Урал. 1918. 21 ноября.

3 Власть народа. 1918.22 ноября.

4 Сибирские стрелки. 1919. 4 мая.

5 Пермская земская неделя. 1919. 25 мая.

6 Красный Урал. 1919. 22 августа.
} 
тических партиях, организациях и собраниях, обсуждающих политические вопросы, равно как и в политических манифестациях, воспрещалось 1 .

Широко использовали большевики и устную агитацию: митинги, лекции. В качестве ораторов и лекторов выступали видные деятели партии: А.Г. Белобородов, Ф.И. Голощекин, И.Т. Смилга, Е.А. Преображенский, Е.М. Ярославский и др. При колчаковском режиме тоже устраивались публичные лекции, которые читали, как правило, профессора Пермского университета. Но если большевики проводили митинги и лекции на злободневные темы, то проблематика лекций профессуры была совершенно другой: «Философия и ее задачи», «Системы социального усовершенствования», «Жизнь растений», «Психология женщины» и т.п.

В стране, где большинство населения было неграмотным, призывы к восстановлению законности и порядка, установлению демократического режима и даже созданию правового государства были не очень понятны и не находили отклика в широких массах. Намного ближе и понятней была «диктатура пролетариата», лозунг «Грабь награбленное!» Как позднее в эмиграции отмечал один из лидеров левых эсеров, бывший нарком юстиции И.З. Штейнберг, «большевики сознательно разжигали народные страсти, играли на тех чертах народного характера, которые поистине являлись варварскими» [Штейнберг 1923: 27]. Это достигалось в т.ч. и с помощью газет. Несмотря на все усилия, противники большевиков проиграли информационную войну.

Статья подготовлена при поддержке РФФИ, грант № 20-09-00443.

\section{Список литературы}

Волгин А.П. 1990. Буржуазная пресса Сибири и колчаковщина: автореф. дис. ... к.и.н. Томск. 20 с.

Заранян Е.В. 2016. Особенности формирования образа врага у белогвардейцев. - История Гражданской войны в России 1917-1922 г2.: материалы международной научно-практической конференции. М.: ЦМВС РФ. С. 358-363.

Карр Э. 1990. Русская революиия от Ленина до Сталина. 1917-1929 (пер. с англ. Л.А. Черняховской). М.: Интер-Версо. 208 с.

Куваева Т.Е., Балашова Л.Н. 2016. Плакаты начального периода Гражданской войны 1917-1919 гг. - История Гражданской войны в России 1917-1922 г2.: материалы международной научно-практической конференции. М.: ЦМВС РФ. С. 286-291.

Молчанов Л.А. 2001. Газетный мир антибольщевистской России (октябрь 1917-1922 г.). М.: Посев. 160 с.

Молчанов Л.А. 2002. Газетная пресса России в годы революции и гражданской войны. М.: Издатпрофпресс. 271 с.

Нарский И.В. 2001. Жизнь в катастрофе: Будни населения Урала в 19171922 г2. М.: РОССПЭН. 632 с.

Наталенко А.Д. 2017. Противостояние «красных» и «белых» в советском плакате. - Молодежь ХХІ века: образование, наука, инновации: материалы VI Всероссийской студенческой научно-практической конференции с международным участием. Новосибирск, 22-24 ноября 2017 г. (под ред. Е.В. Лисецкой). Новосибирск: Изд-во НГПУ. С. 4-5.

Никитин А.Н. 1991. Периодическая печать как источник по истории гражданской войны в Сибири. Омск: Изд-во ВШМ МВД РФ. 204 с.

\footnotetext{
${ }^{1}$ Государственный архив Пермского края. Ф. Р-656. Оп. 1. Д. 9. Л. 30.
} 
Рабинович А. 1989. Большевики приходят к власти: Революция 1917 года в Петрограде (общ. ред. и послесл. Г.З. Иоффе). М.: Прогресс. 416 с.

Штейнберг И.З. 1923. Нравственный лик революции. Берлин: Б.и. 416 с.

OBUKHOV Leonid Arkad'evich, Cand.Sci. (Hist.), Associate Professor of the Chair of Interdisciplinary Historical Studies, Perm State National Research University (15 Bukireva St, Perm, Russia, 614990; obuhovla@yandex.ru) EKHLAKOVA Alina Rinatovna, Assistant at the Chair of Interdisciplinary Historical Studies, Perm State National Research University (15 Bukireva St, Perm, Russia, 614990; alina.perm@mail.ru)

\title{
PERIODICALS AS A SOURCE OF THE INFORMATION WAR HISTORY BETWEEN THE REDS AND WHITES IN THE CIVIL WAR IN THE EAST OF RUSSIA (1917-1920)
}

\begin{abstract}
The article investigates the information confrontation between the Reds and Whites during the Civil War in eastern Russia based on the materials of a number of Ural newspapers. The periodicals were the most massive and popular means of information and an important weapon in the information war. The authors note that the Bolsheviks had a well-established agitation and propaganda apparatus and large circulation of newspapers, but their opponents had to start all over again. In whole, the structure of "red" and "white» newspapers repeats the publications of the pre-Soviet period, therefore the logical composition of the issues and many types of publications and headings were the same in all editions. The article analyzes general and specific features in the information confrontation, differences in the approaches of state, party and independent publications. The images of power, built with the help of publications in newspapers, overlapped and influenced each other at a certain time interval. The authors make a conclusion about factors that influenced the victory of the Reds in the information war. The manner of presentation of material and language of Kolchak's newspapers is largely designed for the intelligent reader. However, the Bolsheviks presented material in their newspapers in a simpler and more accessible manner. Already during the years of the Civil War, the Soviet government paid great attention to the elimination of illiteracy, especially in the Red Army. The Bolsheviks made wide use of oral agitation and organized meetings, lectures. The themes and problems of lectures of «white» professors were completely different and not very clear for the broad masses.

Keywords: Civil War, information war, information confrontation between Reds and Whites, newspaper, east of Russia
\end{abstract}

